
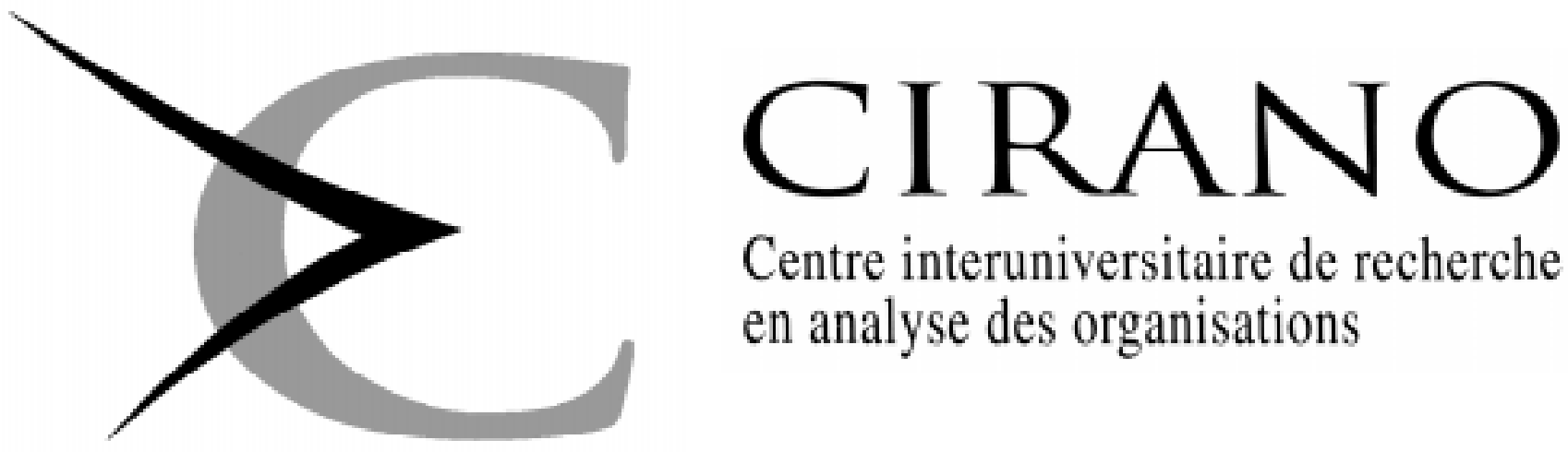

Centre interuniversitaire de recherche en analyse des organisations

Série Scientifique

Scientific Series

98s-28

Explaining Sales Pay Strategy

Using Agency, Transaction Cost

and Resource Dependence Theories

Michel Tremblay, Jérôme Côté,

David B. Balkin 


\section{CIRANO}

Le CIRANO est une corporation privée à but non lucratif constituée en vertu de la Loi des compagnies du Québec. Le financement de son infrastructure et de ses activités de recherche provient des cotisations de ses organisations-membres, d'une subvention d'infrastructure du ministère de l'Industrie, du Commerce, de la Science et de la Technologie, de même que des subventions et mandats obtenus par ses équipes de recherche. La Série Scientifique est la réalisation d'une des missions que s'est données le CIRANO, soit de développer l'analyse scientifique des organisations et des comportements stratégiques.

CIRANO is a private non-profit organization incorporated under the Québec Companies Act. Its infrastructure and research activities are funded through fees paid by member organizations, an infrastructure grant from the Ministère de l'Industrie, du Commerce, de la Science et de la Technologie, and grants and research mandates obtained by its research teams. The Scientific Series fulfils one of the missions of CIRANO: to develop the scientific analysis of organizations and strategic behaviour.

\section{Les organisations-partenaires / The Partner Organizations}

-École des Hautes Études Commerciales

-École Polytechnique

-McGill University

-Université de Montréal

-Université du Québec à Montréal

-Université Laval

-MEQ

-MICST

-Banque Nationale du Canada

-Bell Québec

-Fédération des caisses populaires Desjardins de Montréal et de l'Ouest-du-Québec

-Hydro-Québec

- Industrie Canada

- Microcell Labs inc.

- Raymond, Chabot, Grant, Thornton

- Scetauroute

- Société d'électrolyse et de chimie Alcan Ltée

- Téléglobe Canada

-Ville de Montréal

Ce document est publié dans l'intention de rendre accessibles les résultats préliminaires de la recherche effectuée au CIRANO, afin de susciter des échanges et des suggestions. Les idées et les opinions émises sont sous l'unique responsabilité des auteurs, et ne représentent pas nécessairement les positions du CIRANO ou de ses partenaires.

This paper presents preliminary research carried out at CIRANO and aims to encourage discussion and comment. The observations and viewpoints expressed are the sole responsibility of the authors. They do not necessarily represent positions of CIRANO or its partners. 


\title{
Explaining Sales Pay Strategy Using Agency, Transaction Cost and Resource Dependence Theories*
}

\author{
Michel Tremblay ${ }^{\dagger}$, Jérôme Côtét ${ }^{\ddagger}$ David B. Balkin ${ }^{\mathcal{S}}$
}

\author{
Résumé / Abstract
}

L'objectif de cette étude était d'examiner, auprès d'un échantillon de 325 organisations, l'influence des construits clés relatifs à la théorie de l'agence, la théorie des coûts de transaction et la théorie de la dépendence des ressource sur la proportion du salaire dans l'enveloppe de la rémunération directe du personnel de vente. Le niveau de programmation des tâches, la capacité à observer les comportements, les opportunités de carrière et les ressources financières offertes étaient associés à une augmentation du recours de la composante salariale. En revanche, le degré de difficulté à mesurer les résultats, la disponibilité de ressources reliés aux produits/services et un grand différentiel de performance étaient associés à une diminution de la composante salaire. Les résultats supportent l'argument de l'intégration d'une multitude de perspecttives théoriques pour expliquer le choix des stratégies salariales.

The purpose of this study was to investigate, using data gathered from 325 French-Canadian organizations, the influence of key constructs related to agency, transaction cost and resource dependence theories on the proportion of salary in sales compensation. Level of task programmability, capacity to observe behavior, career opportunities and financial resources offered were associated with an increased use of salary pay. In contrast, difficulty of measuring result outcomes, availability of product/service-related resources and high marginal sales force productivity were associated with decreased use of the salary component. Results supported the argument that integration of multiple theoretical perspectives offered a better explanation of pay policy. However, the results have not supported the ability of market and selling uncertainty to predict the proportion of salary.

\footnotetext{
* Corresponding Author: Michel Tremblay, CIRANO, 2020 University Street, 25th floor, Montréal, Qc, Canada H3A 2A5 Tel: (514) 985-4000 Fax: (514) 985-4039 e-mail: tremblam@cirano.umontreal.ca The authors wish to thank Pro-Vente, FCAR and SSHRC for their technical and financial support.

† École des Hautes Études Commerciales and CIRANO

* Bell Canada

${ }^{\S}$ University of Colorado, Boulder
} 
Mots Clés : Représentants aux ventes, rémunération, théorie de l'agence, théorie des coûts de transaction, théorie de la dépendance des ressources

Keywords : Sales, compensation, agency theory, cost analysis theory, resource dependence theory 


\section{Introduction}

Sales force employees play a key role in organizations (Milkovich, 1988). It is therefore not surprising that the question of their compensation has strategic implications. The literature on sales compensation and sales force management proposes a wide range of factors that potentially influence the percentage of salary versus incentives in sales compensation plans. Four conceptual perspectives tend to provide useful insights on sales compensation: agency, transaction costs, resource dependence and institutional theories (Barringer \& Milkovich, 1998). In the compensation context, the agency theory has been the perspective studied most often (e.g. Balkin \& Gomez-Mejia, 1990; Gerhart \& Milkovich, 1990; Roth \& O’Donnel, 1996; Stroh et al., 1996). The transaction cost perspective was investigated by John and Weitz (1989) and the resource dependence perspective by Pfeffer \& Davis-Blake (1987). Eisenhardt (1988) alone used multiple theories - agency and institutional perspectives - to explain pay policies. To our knowledge, no research to date has considered agency, transaction cost and resource dependence theories simultaneously. In addition, earlier studies on sales compensation have mainly been done with US respondents. This study, using data collected from French-Canadian organizations, provides an opportunity to verify whether these three theories can be applied to diverse cultural environments.

However, as Barringer \& Milkovich (1998) have pointed out, the potential for integrating several theories without creating redundancy and incongruity may be limited. While some convergence exists between these theories, each theory apparently has distinctive attributes and key constructs. Agency theory posits that observability of performance and uncertainty are determinants of control (Eisenhardt, 1988, 1989). The major contribution of transaction cost theory is its consideration of specific human assests (Barringer \& Milkovich, 1998). Furthermore, resource dependence theory assumes that the control of critical resources can influence decisions about pay (Balkin \& Bannister, 1993).

This article will begin with a discussion of agency theory. Two key constructs of this theory will be explored: observability of performance and uncertainty of the sales environment. Hypotheses regarding relationships between these two key constructs and proportion of salary will be formulated. Second, the transaction cost perspective is presented. A number of hypotheses related to transactionspecific assets will be postulated. The third theory mentioned will be that of 
resource dependence, followed by several hypotheses regarding control of critical resources. After a discussion of the results, the paper sets out the limitations of the study and its practical implications, and make some suggestions for future research.

\section{Theories and Hypotheses}

\section{Agency Theory: The Theoretical Framework}

The theoretical framework provided by agency theory is preferred by authors in the field of sales compensation. The theory has its roots in neoclassical organizational economics theories, and can be summarized as the formation of a contract between two parties: the principal (the organization) and the agent (the salesperson). The contract is based on two issues: (1) the agency problem, which presupposes a conflict of interest between the principal and the agent, and the difficulty for the principal to verify how the agent is actually behaving; and (2) the risk sharing problem, which presupposes a different attitude to risk on the part of each of the two parties.

As the theory suggests, an agency problem occurs when the principal is unable to adequately monitor the agent's behavior toward the mandate (in this case, the sale of products and/or services). The importance of the principal's (the firm) having information on the performance of the agent (salesperson) arises from the fact that the interests of the two parties may be contradictory. For the principal, the main objective is to maximize profits, while the agent strives to maximize his or her own compensation. Faced with this clear contradiction, the principal must ensure that the agent will act in the best interests of the firm. To do so, it can select one of two alternatives: it can obtain information on the salesperson's behavior, or it can link the salesperson's compensation to sales results or outcomes. In the former case, the principal needs to know what the agent is doing (Eisenhardt, 1985). Information on the behavior of its salespeople allows the organization or principal to ensure that they will act in the principal's best interests, thus resolving the agency problem. In reality, if the organization knows how its salespeople are behaving, it can pay them a fixed salary since it knows they will act in accordance with the mandate. It will subsequently opt for a "behavioral" type of contract, such as a salary-only compensation plan. In the 
latter case, the most obvious way of countering the agency problem is to offer the salespeople a "results" contract, whereby they are paid on commission or in the form of bonuses according to sales made. However, this option has the effect of transferring the risk to the agent and increasing his or her level of uncertainty. A salesperson's efforts may not necessarily lead to actual sales, thus creating a certain amount of financial risk for that person. As a result, salespeople who work in markets with a high level of uncertainty will probably be less willing to accept a contract based entirely on sales outcomes, unless a substantial premium, in the form of a higher commission, is offered. However, this information comes with its own price tag; the ultimate goal of the organization is to identify the best possible contract that successfully balances the cost of the premium required by the salesperson in exchange for shouldering the environmental risk, and the cost of acquiring information on the salesperson's performance and behavior. This balance may be achieved by a "hybrid" contract, similar to a mixed compensation plan, under which part of the compensation is paid as a fixed salary and the other part as a variable sales-related commission. Two concepts therefore emerge as explanations for the type of contract to be offered to sales staff: first, the organization's ability to obtain information on the performance of its salespeople, and second, the level of uncertainty the salespeople face.

\section{A- The Level of Information on Sales Force Performance}

From the agency theory standpoint, the choice between salary compensation and compensation with a substantial commission component is contingent on the organization's ability to monitor or assess sales force performance. Three factors are examined below: the level of job programmability, the possibility of observing behavior and the ease with which outcomes can be measured.

A programmable task is one whose requisite behaviors can be precisely defined (Ouchi, 1979; Eisenhardt, 1988). If behavior is required to achieve desirable outcomes, sales managers can employ behavioral controls. Two studies by Eisenhardt $(1985,1988)$ in the retail sector showed that the level of job programmability was positively related to the use of a behavioral control in the form of a salary-based plan. Stroh et al. (1996) recent study of a sample of middle managers showed that a high level of task programmability was associated with a more infrequent use of variable pay. Along the lines of 
Eisenhardt and Stroh et al, we can postulate that the greater the level of job programmability, the greater the organizational preference for behavioral control in the form of a larger fixed-compensation component in total compensation. This leads to our first hypothesis, H1.

Hypothesis 1: The level of job programmability will have a positive impact on the amount of fixed compensation in total compensation.

Regarding the ability to measure behavior, Eisenhardt $(1985,1988)$ found that the span of control over the sales force was negatively related to the role of salary. This is based on the argument that a restricted span of control allows sales supervisors to keep a closer eye on their staff and to obtain information on employee behavior more easily. The resulting investment in information leads employers to prefer salary compensation plans. The difficulty and cost of measuring performance have also been examined in the literature. John and Weitz (1989) found a positive relationship between the level of difficulty of measuring outcomes (sales, costs). the contribution of salespeople (input) and the preponderance of the role of salary. Eisenhardt (1985) observed that the cost of acquiring information on sales force performance was related to the presence of a behavioral control - in other words, to the use of a salary plan. Kowtha (1997) showed that performance ambiguity was more strongly related to behavior control than output control. From a slightly different perspective, Anderson (1985) showed that the decision to use an internal (salaried) as opposed to external (commission-based) sales force depended partly on the difficulty in measuring sales force performance objectively, for example in terms of sales and costs. The literature suggests that the possibility of observing behavior is related to the use of a behavioral control, entailing a larger salary component in total sales compensation. This leads to our second hypothesis, H2.

Hypothesis 2: The possibility of observing sales force behavior will be positively related to compensation that includes a larger salary component.

The difficulty of measuring outcomes is enhanced if the sales force is required to engage in nonselling activities, and if input from other people is needed to close sales. The will of organizations to establish longer-term relationships with their customers, and the growing importance of the consumer both demand better 
sales support and the execution of nonselling activities (Anderson and Oliver, 1987; Gomez-Mejia and Balkin, 1992; John and Weitz, 1989). Recent research has shown that performance in nonselling activities had a positive impact on sales results (Cravens et al., 1993). However, it is more difficult to assess performance when salespeople engage in nonselling activities, since their impact on future sales is somewhat uncertain and certain activities may be carried out without the organization's knowledge (John and Weitz, 1989).

Moreover, team selling--which occurs when input from several people is required to close a sale--raises the problem of assessing individual contributions (Ouchi, 1979). In a context marked by high level of task interdependence, whereby a sale is made jointly by two or more salespeople or where salespeople need to work in collaboration with other organizational players (engineers, technicians, etc.), assigning individual responsibility for the sale is more complicated and, consequently, so is allocation of the reward (John and Weitz, 1989; Coughlan and Sen, 1989). To solve this problem, the organization can opt either for team incentives or salary compensation to reward individuals who contributed to the sale of the product or service (Basu et al., 1985; Johnson, 1993). The former option is appealing, but creates its own problems (e.g. freeriding, less recognition for better contributors). Two studies highlighted the influence of teamwork in sales. As expected, John and Weitz (1989) found a positive link between team selling and the presence of a compensation policy based mainly on salary. Cravens et al. (1993) observed that salespeople paid mainly by salary were more likely to prefer team selling, and that this type of compensation policy could be effective. In light of these results, we propose the following hypotheses:

Hypothesis 3A: The difficulty of measuring sales outcomes will be positively related to a larger salary component in total compensation.

Hypothesis 3B: The importance of sales support activities will be positively related to a larger salary component in total compensation.

Hypothesis 3C: The presence of sales made jointly by several individuals will be positively related to a larger salary component 
in total compensation.

\section{B- Level of Uncertainty and Risk Aversion}

From the agency theory perspective, the choice between salary compensation and compensation with a substantial commission component depends on the level of uncertainty in the sales environment and on the capacity or will of the salespeople to accept the financial risk. The risk to the salespeople is that their effort will not produce a sales outcome. The level of risk faced by the agent is closely related to the level of uncertainty. Several sources of uncertainty exist, some related to the sales environment and others to resources available to the individuals.

Uncertainty in the sales environment can stem from at least two sources: the product's sales potential on the market, and the duration of the product sales cycle. A high-growth product with a large market share generates less uncertainty than a product with uncertain growth and a small market share. Agency theorists argue that a high level of uncertainty necessarily leads to less recourse to variable pay (Einsenhardt, 1989). Research by John and Weitz (1989), Eisenhardt (1988) and Kowtha, (1997) has shown that in organizations experiencing a high level of sales instability, extreme difficulty in forecasting sales accurately and a high level of uncertainty about task and sales outcomes, personnel tend to be salaried and control is focused on behavior. In contrast, theoretical prescriptions and empirical studies of strategic compensation contradict agency theory to some extent on this point. These studies suggest that in a context of high uncertainty, organizations must become increasingly flexible, and thus shift from a fixed-salary-based compensation plan to one with a high proportion of variable pay (Stroh et al., 1996). Research by Balkin and Gomez-Mejia (1990 and 1987) showed that mature firms (less uncertainty) tended to favor more salary-oriented compensation, whereas firms in the introductory phase (more uncertainty) tended to prefer a larger incentive component. Stroh et al. (1996) found that the level of uncertainty was associated with an increase in variable pay. It should be noted, however, that neither study was concerned specifically with salespeople, and the life cycle measure was organization-related rather than product-related. 
Some authors have also highlighted the impact of sales cycle duration within the agency theory framework (Coughlan and Sen, 1989; Johnson, 1993). They argue that as the length of time between the initial contact and the closure of the sale increases, so does environmental uncertainty, along with the risk faced by the salesperson. Moreover, in a long sales cycle, measuring the outcome would not enable the organization to identify a reduction of effort by the salesperson. This type of behavior may actually affect the duration of the sales cycle, because if the sale had been made sooner, other customers could have been approached. In such cases, behavioral control in the form of a larger salary component in total compensation is recommended, to encourage salespeople to adopt a long-term approach and to invest time in future sales (John and Weitz, 1989). The work of Coughlan and Narasimhan (1992) contradicts certain precepts of agency theory related to uncertainty. These authors observed a link between the number of calls made to close a sale (greater uncertainty) and the use of incentive-based compensation. From the agency theory standpoint, we can nonetheless postulate that a higher level of uncertainty in the sales environment and sales closure should increase the role of salary in total compensation.

Hypothesis 4: Uncertainty concerning sales outcomes will be positively related to a larger salary component in total compensation.

The resources available to the salesperson, whether in the form of price negotiating power with the customer, the range of products or services sold or similar elements, may reduce the level of uncertainty and, to some extent, facilitate closure of the sale (Lal, 1986; Lal and Srinivasan, 1993). Two types of resources may be made available to the salesperson to facilitate the sale and reduce uncertainty: product resources and financial resources. To date, only John and Weitz (1989) have considered the impact of resources. They showed that the more product resources salespeople have at their disposal (e.g. the possibility of negotiating the product price), the smaller the salary component in total compensation. This leads us to propose the following hypothesis:

Hypothesis 5: The more product-related or service-related resources available to salespeople, the smaller the salary component in total compensation.

Expense accounts may be cover some of the expenses that salespeople incur as 
part of their jobs - for example, vehicle expenses or expenses for attending trade fairs or conferences. A salesperson who does not have an expense account will be personally responsible for such expenses, and will thus run a higher risk, since he or she will have to invest financial resources and personal effort with no prior guarantee of the outcome. From the agency theory standpoint, the expense account is therefore a way for the organization to share the risk with the salesperson, who has a natural risk aversion. On this point, the results obtained by Coughlan and Narasimhan (1992) were ambivalent. They found that sales expenses were negatively related to salary, whereas travel expenses were positively related. In the light of these results, we can propose the following hypothesis:

Hypothesis 6: The extent of the financial resources available will be negatively related to a larger salary component in total compensation.

\section{Transaction Cost Analysis: The Theoretical Framework}

Transaction cost analysis emerged initially from the work of Williamson (1975, 1979, 1985) and, like agency theory, is based on institutional economics. It is distinguished from agency theory by the notion of "contract" (called "transaction" in this case). Transaction cost analysis takes for granted that most contracts are incomplete (because of the limited rationality of the actors and the uncertainty of the outcome) and requires that mechanisms be introduced to avert a situation where the parties, through self-interest, fail to fulfil their obligations (opportunism, in the sense of deceit).

The major contribution of this theory is its consideration of "transaction-specific assets" (TSAs). These are defined as elements held by one of the parties which render the other party dependent. Transaction-specific assets are attached to a single element and therefore cannot be used for another purpose. They may reduce pressure from competition (market failure) and render their holders powerful and in a position to cheat the organization. For this reason, it is recommended that mechanisms be developed to reduce the cost of these elements to a minimum. Consequently, the organization will have to make a choice (often forced) between the transaction costs generated by a "behavioral" 
(or hierarchical) control system and those generated by a "results" control system (market laws). The inherent costs of the former include the investment in behavior observation mechanisms to ensure that the salespeople perform their duties in the desired way. The firm thus reduces its level of uncertainty regarding the performance of its salespeople. When an organization is not faced with a high level of uncertainty and is not dependent on the TSAs of its salespeople, it will tend to opt for market laws, or a "results" control system. The goal here is to reduce the risks of opportunism on the part of the salespeople and to generate a satisfactory effort level. However, this type of system may generate high result measurement costs, which must be considered transaction costs. The costs related to the specific nature of the TSAs and the market laws may lead organizations to attain effectiveness through the use of a "hybrid" type of contract.

To our knowledge, John and Weitz (1989) are the only authors to have attempted to test the link between the TSA construct and the percentage of salary in total sales compensation. Two assets are particularly relevant for our study: investment in training and existence of a career plan. Training, especially in the organization's procedures and products or services, can be described as a transaction-specific asset, because knowledge of one organization's procedures and products is difficult to transfer to another organization. The influence of training on the role of salary has not yet been clearly identified. Coughlan and Narasimhan (1992) found that neither the training budget nor the duration of training explained the type of compensation paid to salespeople. These inconclusive results suggest that further investigation of the phenomenon is required.

The existence of a career plan for salespeople may also be a TSA, since it provides the salespeople with an opportunity to build a career within the organization. It may actually replace higher short-term income. The better the career prospects for salespeople, the higher their future compensation is likely to be (Coughlan and Narasimhan, 1992). Since income potential is higher when compensation is incentive-based, the presence of a career plan for salespeople should be strongly indicative of salary-based compensation where promotion prospects provide the incentive. Solely Coughlan and Narasimhan (1992) have tested this hypothesis. They found a significant positive relationship between the existence of a career plan and a larger salary component. As a result of their 
work, we suggest the following hypothesis:

Hypothesis 7: Career prospects will be positively related to a larger salary component in total compensation.

\section{Resource Dependence Theory: The Theoretical Framework}

The resource dependence model assume that management decisions are influenced by internal and external agents, who control critical resources (Pfeffer $\&$ Salancik, 1978). The resource dependence perspective suggests that some jobs within organizations control resources vital to the survival of the organization. Groups of employees holding these critical jobs are able to derive power from the control of important resources (Balkin \& Bannister, 1993). This power can be used to influence decisions over the formulation of pay policies in keeping with the preferences of the incumbents. Bartol \& Martin (1988) identify four attributes that affect employee control over resources: 1) the degree of uncertainty surrounding the achievement of the task; 2) the importance of task achievement to the organization (centrality); 3) the ease with which the work can be observed and measured, and 4) the level of skill specialization required to perform the tasks. Pfeffer \& Davis-Blake (1987) suggest that the degree to which organizations are dependent on a position may be defined by two variables: the criticality of the position and the substitutability of the position. The resource dependence perspective suggests that the sales representative may play a critical role in the firm when it is able to control the relationship with the customer and the flow of revenues (Balkin \& Bannister, 1993). We argue that the level of competency of the sales force and the level of centrality and substitutability of the sales position influence the pay policy of this strategic employee group.

A competent professional sales team requires fairly stable compensation and a relatively high salary to recognize the true value of the salesperson's opportunity cost of time (Coughlan and Narasimhan, 1992) and to retain the best elements of the organization. These authors observed that the level of education and seniority were positively related to the role of salary. Similarly, Cravens et al., (1993) showed that professional competency was closely related to salary compensation. Generally speaking, salespeople who have made a significant investment in human capital (education, specific experience) are, all other things 
being equal, in a better position to demand safer compensation because of the value of their assets on the job market (Lal and Srinivasan, 1993; Basu et al., 1985). We therefore suggest the following hypothesis:

Hypothesis 8: The level of competence (education, experience) of the sales team will be positively related to a larger salary component in total compensation.

Nonetheless, highly competent salespeople are more likely to see their efforts rewarded by sales outcomes than less competent salespeople. According to Coughlan and Sen (1989), the most productive salespeople should receive a higher portion of variable compensation, because their marginal contribution to the organization's profits is greater than that of their average or weaker colleagues. These critical employees, who control vital resources, namely sales income, are in a better position to capture a portion of their value added to the organization through the pay system (Balkin \& Bannister, 1993). The variable portion of total compensation should conceivably increase while the performance of individual salespeople in the same sales team differs widely, to the employees' marginal contributions and to retain these valuable individuals.

Hypothesis 9: As the disparity between the performance of the salespeople increases, the salary component in total compensation should decrease.

The sales representatives control relationships with the customer when the firm depends primarily on personal selling to the customer to close the sale (Eisenhardt, 1988). In contrast, when a firm spends heavily on advertising and sales promotions to influence customers, the sales representatives is no longer the primary factor that influences the customer to buy the product (Balkin \& Bannister, 1993), defined as "the predominance of the role of the salesperson in closing sales" (Schultz, 1987; Moynahan and Locke, 1988; Gomez-Mejia and Balkin, 1992). Although the effect of the marketing mix strategy on compensation has not been examined, a number of specialists have suggested that investment in certain elements of the marketing mix may diminish the role or importance of the salesperson in closing the sale, and thus the need to pay incentive-based compensation (Coughlan and Sen, 1989; Blessington, 1992; Johnson, 1993; Cespedes, 1990; Anderson et al., 1992). Moreover, some authors have suggested that compensation for salespeople with low marginal 
productivity due to the influence of factors beyond their control on sales closures (low predominance) should be mainly salary-based (Coughlan and Narasimhan, 1992; Lal and Srinivasan, 1993). We therefore suggest the following hypothesis:

Hypothesis 10: The predominance of the salesperson in the organization's marketing mix will be negatively related to a larger salary component in total compensation.

Labor market conditions may affect the extent to which an organization is dependent on external agents for critical human resources. Conditions in the labor market determine the ease which critical resources can be replaced (Barringer \& Milkovich, 1998). Replaceability or substitutability may effect dependence on employee resources and consequently the role of salary. For instance, a high sales staff turnover may suggest that it is fairly easy for salespeople to find other jobs, and for the organization to recruit replacements. This suggests that a more effective contract would compensate the sales force with a higher percentage of variable compensation, and thus bring the market into play. To our knowledge, only John and Weitz (1989) have tested the influence of this particular element. They found a weak positive relationship between the difficulty of replacing salespeople and a higher salary component in total compensation. We can therefore suggest the following hypothesis:

Hypothesis 12: The level of sales staff turnover will be negatively related to a larger salary component in total compensation.

\section{Control variables}

A number of organizational variables may also influence sales compensation significantly and should be controlled in any study seeking to test control theory predictions (Stroh et al., 1996). At the organizational level, an organization's industry membership (Gerhart \& Milkovich, 1990; Stroh et al., 1996) and size (Gerhart \& Milkovich, 1990; Tremblay \& Marcoux, 1994; John \& Weitz, 1989) should be taken into account. 


\section{Methodology}

\section{Sample}

The relationship between the size of the salary component in total sales compensation and the variables obtained from the concepts discussed above was assessed using a questionnaire written in French. The questionnaire was developed and pre-tested in personal interviews with seven sales managers, and then mailed to a wide variety of organizations. The sample was taken from a bank of sales managers provided by a specialized sales management training firm. The bank contained details of nearly 4,000 sales managers (name, address, sector). Sales managers were selected as informants for this research because these individuals are most knowledgeable about sales compensation policies in the firm. In most organizations sales compensation administration occurs within the sales unit of the firm because sales compensation is a critical component of sales and marketing strategy (Gomez-Mejia \& Balkin, 1992).

Survey participants were selected on the basis of economic sector representation, geographical location and the number of managers per organization. The aim was to obtain respondents from different sales environments. After application of the selection criteria, the list of managers obtained from the database was reduced to 2014. Although at first we felt it would not be useful to send the questionnaire to several sales managers from the same establishment, we eventually decided, where possible, to ask two managers from the same establishment to complete the questionnaire, to maximize the chances of a response. Our decision was amply justified by the number of mailed questionnaires returned unopened because the person concerned no longer worked for the organization or because the address was incorrect. The questionnaire was ultimately mailed to all 2014 sales managers in 1247 establishments in Quebec. The Canadian sample provided an opportunity to gather data in a different cultural environment than earlier studies on sales compensation, which mainly covered US and UK respondents. Three weeks after the first mailing, we faxed a reminder to 100 sales managers whose establishments had not yet responded and whose fax number was available. The response rate, calculated as the number of completed questionnaires received as a percentage of the number of establishments to which at least one questionnaire 
was sent $(325 / 1247)$, was $26.1 \%{ }^{1}$. Our study is therefore based on a sample of 325 establishments that completed the questionnaire. The highest number of responses was obtained from the manufacturing sector (32\%), followed by the finance, insurance and real estate sector (28\%), retail sales (17\%), transportation, communications and public utilities (15\%) and services $(6 \%)$. The average number of salespeople per establishment was 14 , and the average number of managers supervising the sales team was two. Respondent establishments had an average sales turnover of $\$ 20.5$ million, and more than half had less than 100 employees. Generally speaking, sales employees had a college education, 12 years of experience in sales, and had worked for the organization for an average of six years. With respect to compensation, 29\% of respondent establishments paid their salespeople on commission only, $11 \%$ by salary only and $60 \%$ had compensation plans comprising a salary component combined with one or more incentives (commission, bonus, profit-sharing).

\section{Measure of Independent Variables ${ }^{2}$}

Two theoretical concepts inherent to control theories were explored in this research: information on agent performance and environmental uncertainty. Three indicators were used to define the concept of information on agent performance: the level of job programmability, the possibility of observing behaviors and the possibility of measuring outcomes. To measure job programmability, we used one item from Eisenhardt's $(1985,1988)$ construct. To assess the ability of managers to observe the behaviour of their salespeople, we used four measures. Like Eisenhardt (1985), we used the ratio (ratio) of sales team size to total number of direct sales team supervisors. Two additional items were examine: the workplace (on the road, coded 1 , or in the office, workplace) and the number of days on the road (days on the road). To assess the ability to measure performance, we used four measures. The first estimated the ability to measure performance as output (measure of outputs). This was done with three statements, the first two taken from the work of John and Weitz (1989) and the

1. In cases where two sales managers from the same establishment responded to the survey, the redundant questionnaire was eliminated from the sample. Thus, each establishment in the sample is represented by the responses of one sales manager.

2. Appendix 1 presents the definition, measure and reference construct for each of the variable studied. 
third developed specifically for our study. This latter dealt with the presence of a computer system to verify salesperson performance by means of quantitative measures. It produced a fairly satisfactory internal confidence indicator $($ Cronbach alpha $=0.80)$. The second measurement attempted to establish the importance of sales support (support activities), and was based on an item originally developed by Cravens et al. (1993). A second item was developed to assess the percentage of time (0\% to 100\%) spent on sales support activities (importance of support). To detect the presence of team sales (team sales), we used the instrument developed by John and Weitz (1989), comprising five items measured on a seven-point Likert scale. Factor analysis revealed an internal confidence indicator similar to that obtained by John and Weitz (1989) $($ Cronbach $=0.78$ vs. 0.76$)$.

For measuring the level of market uncertainty, we used four indicators: market share, growth potential, number of meetings to close a sale and duration of meetings. The literature suggests that the product/service development stage is a good indicator of the level of uncertainty. We opted for the Boston Consulting Group (BCG) matrix. Respondents were asked to situate the product (or products, where applicable) on one of two axes. A product with high growth potential (growth potential, coded 1) or a product holding a major market share (market share, coded 1) indicated a low level of uncertainty. To assess the sales cycle, we used two items: the time needed to close a sale (time to close, hour indicator) and the number of meetings needed to close a sale (number of meetings).

The products resources available to the salespeople were measured by three items: complementarity in the range of products/services (complementary Product, yes $=1$ ), the possibility of adapting the products/services (product adaptability, yes $=1$ ) and the availability of particular resources (Resource availability) to salespeople (e.g. the possibility of negotiating prices with customers, offering discounts on sales, credit, installation or special delivery terms). To operationalize this item, we counted the total number of resources available to create an overall score for each establishment. A further type of resource is the expense account. To assess its presence and identify the type of expenses covered by the organization, we based our question on the measure used by Coughlan and Narasimhan (1992). Respondents were asked to indicate which of the expenses in the list provided were covered by the organization (e.g. car, gas, meals, promotion expenses). We then counted the number of expense 
items for each organization to obtain an overall score (number of expenses). We also asked whether the organization had a discretionary expense account (discretionary expense, yes $=1$ ) and its amount in dollars (size of expense account). The larger the expense account, the lower the level of uncertainty.

To assess the resource dependence perspective, we used five measures: number of years of sales experience (sales experience), level of education (education), level of difference in salesperson performance (performance differential), using a $0 \%$ to $100 \%$ scale [0\% (1) to $100 \%$ (7)], sales staff turnover (turnover), which represents the percentage of employees who leave the establishment each year and the predominance of the sales team in the organization's marketing strategy (sales predominance). A scale based on the work of Hurwich and Moynahan (1988) was developed to assess the importance (from 0\% to 100\%) placed by the organization on the various elements of the marketing mix (sales team, publicity, service, price, quality, distribution, R\&D). A low percentage for the sales team was taken to indicate a low predominance in the organization's marketing strategy.

The transaction cost analysis theory concept tested in this study was the presence of transaction-specific assets. This was measured using four items: training effort required (training effort), assessed on a five-point Likert scale, training budget (training budget), the presence of a career plan (career plan, yes=1) and the number of reporting levels in sales function (number of Levels).

Two control variables were used: establishment size and economic sector. As the establishment size indicator, we selected annual sales turnover (size). For identification of the economic sector, we drew heavily from the classification system developed by a large Canadian consulting firm that conducts periodic surveys of sales compensation. Five sectors were listed: manufacturing (Manufacturing), finance, insurance and real estate (financial), retail trade (retail), services (services) and transportation, communications and public utilities (communications). Each sector was treated as a dummy variable (0 and 1) in comparison with a fifth category "other sectors" (others).

\section{Measuring the Dependent}

Our dependent variable in the study was the salary component in total sales 
compensation. To measure it, we asked respondents to indicate, on a scale from 1 to 100 , the proportion of salary paid as a percentage of total average sales compensation. A low percentage (e.g. between $0 \%$ and 10\%) indicated a commission-based compensation policy, whereas a very high percentage (e.g. $90 \%$ to $100 \%$ ) indicated a mainly salary-based compensation policy. Stroh et al., (1996) argue that the properties of proportions are more attractive than those of ratio: proportions are bounded between zero and one, and are thus readily interpretable, but ratios range from zero to infinity.

\section{Analysis}

The hypotheses were tested using hierarchical multiple regression analysis. In the fist step we entered the organizational control variables. Then we introduced the information on the agent performance construct, followed by the uncertainty construct. In the fourth step we entered the TAC variables and in the fifth step the resource dependence variables were entered. In the last step the results of full model is presented. We applied usefulness analysis to assess the additional contribution of each construct in explaining the role of salary (Darlington, 1968).

The coefficient estimates for each of the equations should be viewed with caution, since the dependent variable--assessed as a salary percentage--is not distributed normally. Like John and Weitz (1989), we examined the impact of this distribution. The model was estimated using a logit model with a sample limited to observation of entirely salary-based plans and entirely commissionbased plans. The results turned out to be fairly similar. In all cases, the coefficient signs were not affected by procedural changes. Where the logit transformation was used on the dependent variable $(0=$ commission, $1=$ salary $)$, the model's explanatory power was reduced because of the weak contribution of the control variable financial sector.

Table 1 shows the means, standard deviations and correlation matrix for all the variables examined. According to the matrix, there was no excessive intercorrelation problem (>0.90). The maximum level of intercorrelation observed was 0.51 , suggesting that the model variables are fairly independent. 
Table 1: Descriptive Statistics and Correlations between Variables $(\mathrm{N}=325)$

\begin{tabular}{|c|c|c|c|c|c|c|c|c|c|c|c|}
\hline Variables & M & SD & 1 & 2 & 3 & 4 & 5 & 6 & 7 & 8 & 9 \\
\hline 1- Proporsal & 46.8 & 37.7 & --- & & & & & & & & \\
\hline 2- Programmation & 2.1 & .70 & -.21 & --- & & & & & & & \\
\hline 3- Ratio & .18 & .13 & .16 & .09 & --- & & & & & & \\
\hline 4- Workplace & .70 & .46 & .09 & .01 & .16 & --- & & & & & \\
\hline 5- Measure of results & 13.8 & 4.5 & -.14 & .07 & -.21 & -.02 & --- & & & & \\
\hline 6- Days on the road & 4.1 & .87 & -.06 & -.11 & -.23 & .01 & .12 & --- & & & \\
\hline 7- Support activities & .55 & .15 & .02 & .07 & -.20 & .34 & .09 & .12 & --- & & \\
\hline 8- Importance of support & 2.95 & 1.47 & -.01 & -.02 & -.01 & -.12 & .06 & -.18 & .01 & --- & \\
\hline 9- Team sales & 19.1 & 6.1 & .25 & -.02 & .18 & .02 & -.03 & -.23 & .24 & .10 & --- \\
\hline 10- Market shares & .84 & .37 & .18 & -.10 & -.02 & .01 & .01 & .08 & -.19 & .05 & .05 \\
\hline 11- Growth potential & .56 & .50 & .01 & .16 & -.05 & .03 & .05 & -.02 & .08 & .03 & .01 \\
\hline 12 Number of meetings & 5.5 & 23.6 & .05 & .08 & -.04 & -.05 & .05 & -.05 & -.04 & .03 & .08 \\
\hline 13- Time to close a sale & 2.6 & 1.2 & .05 & .14 & .03 & -.22 & -.09 & -.07 & -.17 & .14 & .24 \\
\hline 14- Resources availability & 2.72 & 1.47 & .23 & .02 & .16 & -.10 & .14 & -.09 & -.11 & -.02 & .23 \\
\hline 15 Product adaptability & .86 & .34 & .18 & -.09 & .04 & -.08 & -.11 & .21 & -.10 & -.08 & -.08 \\
\hline 16- Product complementarity & .87 & .34 & .14 & .01 & -.02 & -.07 & -.04 & .07 & .02 & .03 & .01 \\
\hline 17- Expenses account & .23 & .42 & -.29 & .09 & -.07 & .22 & .01 & .07 & .16 & -.02 & -.24 \\
\hline 18- Size of expenses & 3.63 & 1.83 & .03 & .22 & -.06 & .25 & -.16 & -.04 & .03 & .11 & .16 \\
\hline 19- Number of expenses & 6.16 & 3.87 & .53 & -.28 & .10 & -.26 & -.09 & -.05 & -.27 & .06 & .27 \\
\hline 20- Training effort & 3.88 & .93 & -.04 & .06 & -.02 & -.03 & .22 & .05 & -.05 & .13 & .10 \\
\hline 21- Training budget & 3.05 & 1.39 & -.02 & .01 & -.28 & -.09 & .30 & .05 & .04 & .01 & -.01 \\
\hline 22- Career plan & .50 & .50 & .05 & .11 & .14 & .13 & -.21 & .03 & -.07 & -.06 & .10 \\
\hline 23- Number of levels & 3.44 & 1.35 & .14 & -.24 & -.15 & -.08 & .09 & .07 & .07 & .01 & -.10 \\
\hline 24- Sale predominance & 3.19 & 1.52 & -.19 & .01 & -.12 & -.18 & .10 & .06 & -.02 & .10 & -.18 \\
\hline 25- Performance differential & 4.40 & 1.42 & -.37 & .08 & -.14 & -.10 & .11 & -.05 & .04 & -.01 & -.10 \\
\hline 26- Experience & 2.40 & .95 & .02 & -.11 & .04 & -.19 & -.09 & .03 & -.20 & .13 & .14 \\
\hline 27- Education & 1.95 & .70 & .16 & -.01 & -.04 & -.14 & -.02 & -.11 & -.16 & .01 & .09 \\
\hline 28- Turnover & 1.96 & 1.28 & -.20 & .22 & .02 & .20 & .04 & .05 & .15 & -.10 & -.16 \\
\hline 29- Size of firm & 4.4 & 2.2 & .41 & -.12 & -.06 & -.03 & .01 & .01 & .01 & -.07 & .15 \\
\hline 30- Retail & .17 & .37 & -.10 & .30 & .27 & .46 & .06 & -.06 & .20 & -.09 & -.03 \\
\hline 31- Manufacturing & .32 & .47 & .28 & -.27 & -.01 & -.35 & -.09 & .25 & -.21 & -.03 & .09 \\
\hline 32- Financial & .27 & .45 & -.44 & .02 & -.25 & -.09 & .07 & -.02 & -.01 & .08 & -.22 \\
\hline 33- Services & .06 & .24 & .10 & .03 & .08 & .09 & -.07 & -.03 & .05 & -.01 & .14 \\
\hline 34- Communication & .14 & .35 & .19 & .02 & -.04 & .03 & .02 & -.22 & .05 & .04 & .15 \\
\hline
\end{tabular}


Table 1 (cont'd)

\begin{tabular}{|c|c|c|c|c|c|c|c|c|c|c|c|c|c|c|}
\hline 10 & 11 & 12 & 13 & 14 & 15 & 16 & 17 & 18 & 19 & 20 & 21 & 22 & 23 & 24 \\
\hline & & & & & & & & & & & & & & \\
\hline & & & & & & & & & & & & & & \\
\hline & & & & & & & & & & & & & & \\
\hline & & & & & & & & & & & & & & \\
\hline & & & & & & & & & & & & & & \\
\hline & & & & & & & & & & & & & & \\
\hline & & & & & & & & & & & & & & \\
\hline & & & & & & & & & & & & & & \\
\hline & & & & & & & & & & & & & & \\
\hline --- & & & & & & & & & & & & & & \\
\hline-.03 & --- & & & & & & & & & & & & & \\
\hline .08 & .05 & --- & & & & & & & & & & & & \\
\hline-.04 & -.06 & .20 & --- & & & & & & & & & & & \\
\hline .17 & .03 & .18 & .14 & --- & & & & & & & & & & \\
\hline .10 & -.16 & -.04 & .09 & -.09 & --- & & & & & & & & & \\
\hline .13 & .08 & -.04 & .03 & .07 & .16 & --- & & & & & & & & \\
\hline-.15 & -.02 & -.13 & -.09 & -.23 & .01 & -.11 & --- & & & & & & & \\
\hline .11 & .01 & .05 & .27 & -.11 & -.16 & .06 & .10 & --- & & & & & & \\
\hline .24 & -.07 & .05 & .25 & .37 & .13 & .20 & -.45 & .01 & --- & & & & & \\
\hline-.08 & .14 & .06 & .07 & -.03 & -.14 & -.08 & .10 & .15 & .01 & --- & & & & \\
\hline .08 & .06 & .04 & -.06 & .01 & -.07 & -.03 & .02 & -.10 & -.03 & .20 & --- & & & \\
\hline-.09 & -.10 & .02 & .10 & .02 & .04 & .10 & .04 & .14 & .01 & -.25 & -.29 & --- & & \\
\hline .07 & .04 & .01 & -.13 & .03 & .01 & .01 & -.04 & .04 & .09 & .27 & .37 & -.41 & --- & \\
\hline .11 & .11 & -.02 & .01 & -.02 & -.05 & -.16 & .04 & .21 & -.20 & .20 & .04 & -.22 & .09 & --- \\
\hline .10 & .10 & .06 & -.02 & .16 & -.12 & .08 & .18 & .23 & .32 & .08 & .13 & .10 & .10 & .22 \\
\hline-.06 & -.06 & -.02 & .07 & .11 & .04 & .01 & -.26 & .08 & .30 & -.09 & .01 & .11 & -.11 & -.09 \\
\hline .21 & .21 & .04 & .25 & .02 & .06 & -.03 & -.14 & .23 & .21 & .21 & .12 & -.21 & .13 & .12 \\
\hline-.17 & .06 & -.05 & -.08 & -.15 & -.04 & -.06 & .23 & -.08 & -.38 & .08 & .07 & -.08 & .07 & .17 \\
\hline .13 & -.06 & -.02 & .09 & .20 & .19 & .21 & -.14 & .06 & .39 & -.10 & .28 & .03 & .26 & -.19 \\
\hline-.07 & -.06 & .09 & -.12 & .12 & .01 & .01 & .17 & -.07 & -.21 & -.09 & .01 & .12 & -.09 & -.11 \\
\hline .17 & -.16 & .03 & .14 & .21 & .20 & .23 & -.26 & -.05 & .51 & -.05 & .05 & .10 & .01 & -.16 \\
\hline-.18 & .09 & -.07 & -.13 & -.47 & -.18 & -.23 & .24 & .33 & -.44 & .21 & .09 & -.22 & .10 & .29 \\
\hline .02 & .09 & -.03 & .01 & .02 & -.06 & -.04 & -.02 & -.22 & .01 & -.13 & -.21 & -.04 & -.12 & -.02 \\
\hline .02 & .09 & -.02 & .11 & .16 & -.05 & -.04 & -.11 & .07 & .11 & .02 & .06 & .04 & .03 & .01 \\
\hline
\end{tabular}


Table 1 (cont'd)

\begin{tabular}{|c|c|c|c|c|c|c|c|c|c|c|}
\hline Variables & 25 & 26 & 27 & 28 & 29 & 30 & 31 & 32 & 33 & 34 \\
\hline \multicolumn{11}{|l|}{ 1- Proporsal } \\
\hline \multicolumn{11}{|l|}{ 2- Programmation } \\
\hline \multicolumn{11}{|l|}{ 3- Ratio } \\
\hline \multicolumn{11}{|l|}{ 4- Workplace } \\
\hline \multicolumn{11}{|l|}{ 5- Measure of results } \\
\hline \multicolumn{11}{|l|}{ 6- Days on the road } \\
\hline \multicolumn{11}{|l|}{ 7- Support activities } \\
\hline \multicolumn{11}{|l|}{ 8- Importance of support } \\
\hline \multicolumn{11}{|l|}{ 9- Team sales } \\
\hline \multicolumn{11}{|l|}{ 10- Market shares } \\
\hline \multicolumn{11}{|l|}{ 11- Growth potential } \\
\hline \multicolumn{11}{|l|}{12 Number of meetings } \\
\hline \multicolumn{11}{|l|}{ 13- Time to close a sale } \\
\hline \multicolumn{11}{|l|}{ 14- Resources availability } \\
\hline \multicolumn{11}{|l|}{15 Product adaptability } \\
\hline \multicolumn{11}{|l|}{ 16- Product complementarity } \\
\hline \multicolumn{11}{|l|}{ 17- Expenses account } \\
\hline \multicolumn{11}{|l|}{ 18- Size of expenses } \\
\hline \multicolumn{11}{|l|}{ 19- Number of expenses } \\
\hline \multicolumn{11}{|l|}{ 20- Training effort } \\
\hline \multicolumn{11}{|l|}{ 21- Training budget } \\
\hline \multicolumn{11}{|l|}{ 22- Career plan } \\
\hline \multicolumn{11}{|l|}{ 23- Number of levels } \\
\hline \multicolumn{11}{|l|}{ 24- Sale predominance } \\
\hline 25- Performance differential & --- & & & & & & & & & \\
\hline 26- Experience & -.11 & --- & & & & & & & & \\
\hline 27- Education & .04 & -.12 & --- & & & & & & & \\
\hline 28- Turnover & .19 & -.42 & -.08 & --- & & & & & & \\
\hline 29- Size of firm & .19 & .17 & .08 & -.24 & --- & & & & & \\
\hline 30- Retail & .01 & -.06 & -.22 & .23 & .09 & --- & & & & \\
\hline 31- Manufacturing & .30 & .24 & .06 & -.29 & .19 & -.31 & --- & & & \\
\hline 32- Financial & .36 & -.13 & .01 & .16 & -.29 & -.27 & -.42 & --- & & \\
\hline 33- Services & -.08 & -.04 & .12 & -.08 & -.01 & -.11 & -.18 & -.16 & --- & \\
\hline 34- Communication & -.01 & -.03 & .08 & .03 & .04 & -.18 & -.28 & -.25 & -.11 & --- \\
\hline
\end{tabular}




\section{Results}

Table 2 shows the results for the different models using regression analysis. The first model regressed the proportion of salary on organization control variables. This model was significant $\left(\mathrm{F}=13.68\right.$, p.<.01, adjusted $\left.\mathrm{R}^{2}=.23\right)$. Organizational size $(\beta=.28, \mathrm{p}<.01)$ is positively related to a salary-based compensation strategy. Two economic sectors stand out in particular. Compared with other sectors, the salary component was found to be smaller, or the incentive component greater, in the retail trade sector $(\beta=-.24, p<.05)$ and the finance and insurance sector $(\beta=-.43, \mathrm{p}<.01)$. The regression coefficients in the combined model (Model 6) show that size and sector are particularly robust and accurate predictors of the type of sales compensation paid. 
Table 2: Results of Regression Analysis for Proportion of Pay ${ }^{\mathrm{a}}$ ( $\left.\mathrm{N}=300\right)$

\begin{tabular}{|c|c|c|c|c|c|c|}
\hline Variables & $\begin{array}{c}\text { Control } \\
\text { Variables }\end{array}$ & \begin{tabular}{|c|} 
Performance \\
Information
\end{tabular} & $\begin{array}{c}\text { Sales } \\
\text { Uncertainty }\end{array}$ & $\begin{array}{c}\text { Specific } \\
\text { Assets }\end{array}$ & $\begin{array}{c}\text { Resource } \\
\text { Dependence }\end{array}$ & $\begin{array}{c}\text { Full } \\
\text { Model }\end{array}$ \\
\hline Size & $.28 * * *$ & & & & & $.18 * * *$ \\
\hline Retail & $-.24 * * *$ & & & & & $-.28 * * *$ \\
\hline Manufacturing & -.01 & & & & & -.09 \\
\hline Financial & $-.44 * * *$ & & & & & $-.25 * * *$ \\
\hline Comunication & .03 & & & & & -.04 \\
\hline \begin{tabular}{|l} 
Services \\
\end{tabular} & .01 & & & & & -.04 \\
\hline Programmability & & $.23 * * *$ & & & & -.08 \\
\hline Span of Control & & $.11 * *$ & & & & $.12 * *$ \\
\hline Workplace & & -.09 & & & & $-.18^{* * *}$ \\
\hline Measure of outputs & & $-.10^{*}$ & & & & -.05 \\
\hline Days on the road & & -.01 & & & & -.03 \\
\hline Support activities & & .09 & & & & $.11 * *$ \\
\hline Importance of support & & -.02 & & & & .01 \\
\hline Team sales & & $.24 * * *$ & & & & $.10^{* *}$ \\
\hline Market share & & & .03 & & & .01 \\
\hline Growth potential & & & .03 & & & .03 \\
\hline Number of meetings & & & .06 & & & $.10 * *$ \\
\hline Time to close a sale & & & $-.10 *$ & & & $-.09 *$ \\
\hline Resource availability & & & -.07 & & & -.07 \\
\hline Product adaptability & & & $-.14 * * *$ & & & $-.11 * *$ \\
\hline Product complementary & & & -.02 & & & -.01 \\
\hline Expense account & & & .08 & & & .08 \\
\hline Size of account & & & .03 & & & .03 \\
\hline Number of expenses & & & $.48 * * *$ & & & $.27 * * *$ \\
\hline Training effort & & & & -.06 & & .02 \\
\hline Training budget & & & & -.04 & & .03 \\
\hline Career plan & & & & $-.10 *$ & & -.03 \\
\hline Number of levels & & & & $.21 * * *$ & & .07 \\
\hline Sale experience & & & & & -.06 & $-.11 * *$ \\
\hline Education & & & & & $.16^{* * * *}$ & .06 \\
\hline Sale predominance & & & & & $-.10 *$ & .02 \\
\hline Performance differential & & & & & $-.34 * * *$ & $-.15^{* * * *}$ \\
\hline Turnover & & & & & $-.13 * *$ & -.01 \\
\hline Multiple R & .50 & .38 & .54 & .19 & .43 & .72 \\
\hline $\mathrm{R}^{2}$ & .25 & .14 & .29 & .04 & .19 & .51 \\
\hline Adjusted $\mathrm{R}^{2}$ & .23 & .12 & .27 & .03 & .17 & .46 \\
\hline $\mathrm{F}$ & $13.68 * * *$ & $6.4 * * *$ & $12.13 * * *$ & $3.0^{* * *}$ & $13.9 * * *$ & $27.5^{* * * *}$ \\
\hline
\end{tabular}

\footnotetext{
${ }^{a}$ Standardized regression coefficents $* \mathrm{p}<.10 \quad * * \mathrm{p}<.05 \quad * * * \mathrm{p}<.01$
} 
The second model presents the results of information on agent performance construct. The overall model was significant $\left(\mathrm{F}=6.4, \mathrm{p}<.01\right.$, adjusted $\left.\mathrm{R}^{2}=.12\right)$. The results concerning job programmability confirm hypothesis 1 which states that high programmability is related to a larger salary component in total compensation $(\beta=-.23, p<.01)$. However, the explanatory power of this variable appeared to be relatively weak, since this indicator made a nonsignificant independent contribution when the parameters of the other constructs were included (see model 6). The capacity to observe the behavior of the salespeople partly explains the proportion of the salary component, confirming hypothesis 2 . Where the sales force works mainly from the office ( $\beta=-.10, p<.10, \beta=-.19, p<.01$ in full model), and is closely supervised ( $\beta=.11, p<.05, \beta=.12, p<.05$ in full model), sales staff tend to receive a larger percentage of their total compensation in the form of salary. The difficulty of measuring outcomes $(\beta=-.10, p<.10)$ was also positively related to a larger salary component in total compensation. The results also show that where sales requires interventions from several people to close a sale $(\beta=.24, \mathrm{p}<.01$, $\beta=.10, p<.05$ in full model), and where performance of sales support activities is necessary $(\beta=.11, p<.05$ in full model 6$)$, the sales staff received a larger percentage of their total compensation in the form of salary. These results support hypotheses $3 \mathrm{~A}, \mathrm{~B}$ and $\mathrm{C}$.

Regarding sales environment uncertainty, the results show that model 3 is significant $\left(\mathrm{F}=12,13, \mathrm{p}<.01\right.$, adjusted $\left.\mathrm{R}^{2}=.27\right)$. Hypothesis 4 , however, is not supported. None of the variables related to uncertainty concerning sale outcomes (market share, potential growth, number of meetings and time to close a sale) made an independent contribution of up to .05. The results revealed, however, that the resources related to the product or services and the financial resources are significant predictors of the type of sales compensation paid. The more freedom salespeople have in adapting the product to suit customer requirements $(\beta=-.14, \mathrm{p}<.01, \beta=-.11, \mathrm{p}<.05$ in the full model), the more likely it is that salespeople will be paid in the form of variable pay. Moreover, the more sales-related expenses the organization agrees to pay $(\beta=.48, p<.01, \beta=.27, p<.01$ in the full model $)$, the more likely it is that salespeople will be paid by salary. If hypothesis 5 is supported, the results concerning financial resources contradicted hypothesis 6 . We will return to this latter point later in the discussion. 
Model 4 assessed the contribution of the transaction-specific asset construct. The model was significant $(\mathrm{F}=3.0, \mathrm{p}<.05)$, but the contribution of TSA measures studied was very low, explaining only $3 \%$ of the salary percentage variance in total compensation. However, the results partly support our hypothesis 7 which states that where assets are firm-specific, the firm will tend to pay a higher percentage of salary. Organizations with more reporting levels in the sales function $(\beta=.21, \mathrm{p}<.01)$ and those who provide a career plan for their salespeople $(\beta=-.10, p<.10)$ tended to pay a higher percentage of salary. Neither training effort nor training budget made a significant contribution.

Model 5 presents the results of the resource dependence construct. The overall model was significant $\left(\mathrm{F}=13.9, \mathrm{p}<.01\right.$, adjusted $\left.\mathrm{R}^{2}=.17\right)$. Hypotheses 8 to 12 were partly supported. The higher the differential between the performance of salespeople working for the same establishment $(\beta=-.34, p<.01, \beta=-.15$, $\mathrm{p}<.01$ in full model), the stronger the predominance of the role of salespersons in closing sales $(\beta=-.10, p<.10)$ and the higher the level of sales staff turnover $(\beta=-.13, p<.05)$, the smaller the salary component in total compensation. The results for professional competency were somewhat contradictory and nonrobust, showing that a better-educated sales force $(\beta=16, p<.05$ in model 5, but non-significant in the full model) will be paid a larger salary component, and a more experienced salesperson will receive a larger incentive component ( $\beta=11, p<.05$ in full model, but non-significant in model 5).

As for the additional value of each construct studied, Table 3 presents the results of the usefulness analysis. The analysis assesses the incremental contribution of a specific construct after taking into account the influence of all other constructs and variables. The table shows that addition of organization control variables $\left(\Delta \mathrm{R}^{2=}=.05, \mathrm{~F}=5.1, \mathrm{p}<.01\right)$, of information on agent performance $\left(\Delta \mathrm{R}^{2=}=.06, \mathrm{~F}=4.3, \mathrm{p}<.01\right)$, sales uncertainty $\left(\Delta \mathrm{R}^{2=}=.07\right.$, $\mathrm{F}=3.7, \mathrm{p}<.01)$, and resource dependence constructs $\left(\Delta \mathrm{R}^{2=}=.03, \mathrm{~F}=3.8, \mathrm{p}<.01\right)$ resulted in significant improvement of $\mathrm{R}^{2}$ in the proportion of salary. The addition of the TSA construct did not result in a significant improvement in a $\mathrm{R}^{2}\left(\Delta \mathrm{R}^{2=}=.01, \mathrm{~F}=.78, \mathrm{p}<.34\right)$. 
Table 3: Results of Usefulness Analysis

\begin{tabular}{|l|c|c|}
\hline & $\Delta \mathbf{R}^{\mathbf{2}}$ & $\mathbf{F}$ \\
\hline $\begin{array}{l}\text { Control variables beyond Performance information, } \\
\text { Uncertainty, Specific Assets, Resource dependence }\end{array}$ & .05 & $5.3^{* *}$ \\
\hline $\begin{array}{l}\text { Performance Information beyond Control variables, } \\
\text { Uncertainty, Specific Assets, Resource dependence }\end{array}$ & .06 & $4.3^{* *}$ \\
\hline $\begin{array}{l}\text { Uncertainty beyond Control variables, Performance } \\
\text { Information, Specific Assets, Resource dependence }\end{array}$ & .07 & $3.7^{* *}$ \\
\hline $\begin{array}{l}\text { Specific Assests beyond Control variables, Performance } \\
\text { Information, Uncertainty, Resource dependence }\end{array}$ & .01 & .80 \\
\hline $\begin{array}{l}\text { Dependence Resource beyond Control variables, } \\
\text { Performance Information, Uncertainty, Specific Assets }\end{array}$ & .03 & $3.8^{* *}$ \\
\hline
\end{tabular}

$* * \mathrm{p}<.01$

\section{Discussion}

The contribution of this paper is that its empirical research investigates three major theoretical frameworks relating to sales compensation: agency theory, transaction cost analysis, and resource dependence theory. The findings suggest that variables derived from these three theories yield more powerful and useful insights into the role of salary in the context of sales than one individual perspective alone. The full model explained $46 \%$ of variance in the proportion of salary compared with $12 \%$ for the agent information performance model, $27 \%$ for the ales uncertainty model, $17 \%$ for the resource dependence model and $3 \%$ for the transaction-specific assets model. The usefulness analysis has also shown, that except for transaction-specific asset constructs, all of the other constructs derived from organizational theories provided robust independent contributions in explaining sales compensation. The data for this study were collected from French-speaking Canadian respondents, providing a different cultural context from previous research gathered from English-speaking employees. This study suggests that constructs and variables derived from the perspectives studied can be applied 
to diverse cultural environments.

Regarding specific results, as we postulated in hypothesis 1, high job programmability is related to a larger salary component in total compensation. As predicted, organizations appear to use incentives or variable pay to align the goals of their salespeople with those of organizations when tasks are less programmable. Although the contribution of this concept is fairly modest and robust, the results partly confirm Eisenhardt's $(1985,1988)$ findings regarding sales force and Stroh et al., (1996) for middle-level managers. It should be remembered, however, that Eisenhardt worked on a very specific sector - shoe manufacturing - whereas our own research spanned a variety of sectors. Moreover, several of the organizations in our sample manufactured and sold a wide range of products or services, and the choice of responses may not have been universally appropriate. Therefore, perhaps it is better to work with sector-specific programmability constructs.

Regarding hypothesis 2 , the influence of the possibility of observing behavior was confirmed. The results concerning the workplace revealed that sales staff are paid a higher percentage of salary when they are mainly office-based, and a higher percentage of commissions when they work mainly outside the office or on the road. Surprisingly, the number of days on the road had no effect on the compensation strategy. We found that when salespeople spent less than two days on the road, they were paid a higher percentage of salary $(63 \%)$, and when they spent more than half the week outside the office (3 days or more), they tended to be paid more on results. However, the percentage did not subsequently vary according to the number of days. As far as we know, this research is the first to have highlighted the impact of the workplace on sales compensation. As expected, the supervision ratio had a positive impact on the salary component. Our hypothesis on the impact of behavioral observation, and consequently Eisenhardt's (1985) conclusions, are thus confirmed. The lower the span of control for the sales managers, the easier it is to supervise salespeople and observe their behaviour, and the less useful incentive compensation will be. Like John and Weitz (1989), and in accordance with hypothesis 3 , we observed that the difficulty of measuring sales performance in the form of outcomes had a negative impact on the salary percentage. The positive impact of sales support activities and teamwork on the salary component was confirmed. Like Anderson (1985) and Cravens et al. (1993), we found a relationship between the scope of sales support activities and a 
larger salary component in total compensation. This result suggests that, to motivate salespeople to perform nonselling tasks or activities, organizations should provide them with more pay stability. As for the importance of team selling, our results confirmed those of John and Weitz (1989) and Cravens et al. (1993) for the same type of population. It would be interesting, in future research, to see whether organizations that encourage teamwork opt for group or individual compensation.

Our results concerning hypothesis 4 , related to concept of uncertainty with respect to agency theory, show that uncertainty sales outcomes has no influence on compensation strategy. However, we observed a positive correlation $(\mathrm{r}=0.18, \mathrm{p}<.05)$ between market share and salary percentage. This may be due to the instrument used. Some respondents were perhaps not familiar with the BCG grid, which required them to situate their product along one of two axes. Establishments with extensive product ranges must have found this difficult. In addition, we cannot dismiss the social desirability bias. Few organizations are proud of selling so-called "dead wood" products or services. The impact of the number of meetings and the time required to close a sale was found to be limited. In both cases, the relationship with salary percentage was U-shaped. The salary percentage was relatively high in contexts with low levels of uncertainty (fast closure of sales), then dropped steeply in contexts with average uncertainty, and rose again in contexts with very high uncertainty (long, difficult closures). We have assessed these curvilinear relationships by transforming independent variables in square terms. The results show that square terms created a marginal improvement over the linear model $(\beta=.07$ and $\beta=-.08, p<.10)$. This suggests that the concept of uncertainty requires a much more sophisticated examination than the literature would have us believe.

In keeping with hypothesis 5, our results showed that product-related resources were negatively related to salary percentage. The more flexibility the sales force has in adapting products and services to suit specific customers or consumer needs, the smaller the salary component in their total compensation. This result is consistent with the findings of John and Weitz (1989). However, since the hypotheses underlying the other construct variables were not verified (complementary products and particular resources), it would be premature to conclude that product/service-related resources have an impact on sales compensation. With respect to hypothesis 6 , 
bearing on financial resources, our results show that the total number of expenses paid by the organization has a positive impact on salary percentage. This is a direct contradiction of our hypothesis. We found that the more willing organizations were to pay sales expenses, the more likely they were to pay their sales staff a higher salary percentage. A possible explanation for this is that some reimbursable expenses are classified as fringe benefits or "perks" for the sales team. If this were the case, reimbursement of selling expenses would not be considered when establishing compensation policies, but would instead be part of the fringe benefit package. This assumption was supported by a fairly high correlation $(r=.25, \mathrm{p}<.01)$ between the seniority of salespeople, sales staff turnover $(r=-.37 ; \mathrm{p}<.01)$ and the total number of expenses paid by the organization. As fringe benefits usually increase with seniority and decrease with staff turnover, our argument seems well founded. If we push this line of reasoning further, it is not improbable that reimbursement of selling expenses is offered instead of or in exchange for incentive compensation. Some organizations, knowing their salespeople have a natural aversion to risk, have agreed to pay some sales expenses instead of increasing the commission or performance bonus component of total compensation. There may also be tax-related reasons for the strategy. Sales people are less likely to pay taxes on business meals or travel than they would on sales bonuses and commissions.

The study showed that human assets specifically required to perform the job, the specific attribute of the transaction cost analysis perspective, plays a significant but limited role in explaining sales compensation practices. As expressed by hypothesis 7 , the presence of the career plan and the number of reporting levels in the sales function were found to be particularly useful asset specificity indicators for understanding the type of compensation paid. Although our results confirm those obtained by Coughlan and Narasimhan (1992) to a point, our analyses also revealed that compensation policies are determined most strongly by actual prospects for promotion than by the presence of a formal career plan. The more reporting levels in the sales function within an organization, the better the future salary prospects, and the greater the incentive provided. Finally, like John and Weitz (1989) and Coughlan and Narasimhan (1992), we found no significant relationship between investment in training and sales compensation strategy. These inconclusive results may be explained by the difficulty of accurately 
measuring the actual training effort for a particular group of employees, and the reticence of firms to reveal their figures.

The results show that the resource dependence perspective is a useful framework to explain salary strategy. Contrary to hypothesis 8 , we observed that experience in selling was negatively related to the percentage of salary paid. Coughlan and Narasimhan (1992) observed the same relationship. This suggests that organizations may be aware of the importance of recognizing the marginal contribution of experienced salespeople and the need to retain these valuable resources. Additionally, when experience in sales increases, so does accountability (Kowtha, 1997). The increase in the level of accountability for results required a shift in direction of a higher proportion of variable pay. The impact of the level of education on the salary component was confirmed. Coughlan and Narasimhan (1992) had observed a similar relationship. This result may be explained by the fact that a hiring policy requiring a higher level of education creates a greater entry barrier, and consequently pressure for a greater salary component in total compensation (Moynahan and Locke, 1988). Alternately, salespeople who have made a significant investment in human capital are well positioned to demand safer compensation because of the value of their assets on the job market (Lal and Srinivasan, 1993; Basu et al., 1985).

Hypothsis 9, suggesting that the difference between the performance of an average salesperson and the performance of an exceptional salesperson will be negatively related to the size of the salary component in total compensation, has been fully confirmed. This research is the first to have identified such a relationship, and clarifies wage survey data indicating substantial differences in income between average and exceptional salespeople paid under variable compensation programs. This result may be explained by the fact that the best performers are generally more attractive and have better opportunities on the market. They can thus find it easier to leave for a rival firm or start their own business. Sharing organizational or individual success with these employees apparently represents an indicated compensation strategy to retain these valuable salespeople.

However, hypothesis 11 concerning the impact of sales force predominance in the organization's marketing strategy was partly supported. We observed a small negative relationship between the degree of predominance of the sales force and the proportion of the salary component. We believe that sales force 
predominance must be alongside other marketing mix elements. More detailed analysis is required to identify emergent marketing strategies and assess whether particular configurations explain sales compensation policies more effectively. In accordance with hypothesis 12 we found a negative relationship between sales staff turnover and the size of the salary component in total compensation. This may suggest that it is easier to replace the sales team, and supports the argument that where the level of human resource dependence is low, organizations should let the market rule.

Lastly, concerning the influence of organizational variables, our results show that the size of the establishment is positively related to salary percentage. The most plausible explanation for this is that large firms have more financial resources and can take advantage of economies of scale that allow them to pay a larger salary component. Our analyses showed that the salary percentage increased with size regardless of the sales environment, sector, type of product or sales force characteristics. According to institutional theory, it is more difficult to change compensation policies and adapt them to new sales contexts as size increases (Greening \& Gray, 1994; Barringer \& Milkovich, 1998) Reducing the salary percentage or replacing it with more incentive-based compensation appears to be a somewhat delicate operation, and one that is difficult to justify to employees in large organizations. It should also be remembered that size is a determining factor in pay surveys (Crystal, 1991). Firms commonly compare themselves with other firms of the same size. Moreover, our cross-sectional data do not allow us to advance that organizational size is a factor of institutionalization of pay policies. Our results suggest, however, that the role of size must be explored more carefully in studies of compensation. In this regard, institutional theory is a useful framework for measuring how external agents (e.g. governments, professional associations, survey firms) and internal pressure agents (e,g, unions, group interests) in medium and larger organizations influence the choice of pay strategies.

Our research also showed the influence of the sector. Similar to Stroh et al. (1996), we observed that retail and financial industries used a higher proportion of variable pay. Distribution analysis of salary percentages by sector showed strong similarities in some subsectors, especially insurance and car sales. Although there are some similarities in products and markets in a given sector, this does not justify the fact that most establishments in that 
sector adopt the same sales compensation policies. As Crystal (1991) observed for senior managers, pay surveys may perpetuate compensation policies in a given sector. Although our analyses were not revealed to be a good evidence of isomorphism by tradition, as Eisenhardt (1988) demonstrated, a form of isomorphism by imitation nevertheless probably exists in the field of sales compensation. However, the importance of industry membership suggests that studies seeking to test organizational control theory predictions in the field of compensation must take into account this organizational characteristic.

\section{Avenues for future research}

Our study led us to identify a number of avenues for future research. Although our research is the first in field of sales compensation to have integrated basic constructs related to agency, transactional cost analysis and resource dependence perspectives, the consideration of institutional theory may add useful insights into compensation decision-making. Following John and Weitz's (1989) reasoning, it would be interesting to develop a conceptual framework and test the causal links between organizational control theory variables. The framework proposed by Gomez-Mejia and Balkin (1992) is an interesting starting point. As they suggest, do the product characteristics, market predominance and span of control have only an indirect effect on compensation strategies as moderated by job design? So far, researchers have concentrated on explaining the use of salary or commission, the size of the salary component in total compensation and the level of salary. Sales compensation is much more complex, and takes many different forms (e.g. salary and bonus, salary and commission, salary, bonus and commission). It would be interesting to explore why organizations opt for one particular combination rather than another, and the importance of commissions and bonuses. To our knowledge, no research to date has tested the effectiveness of the theoretical models by sector. Can the same determinants be generalized over several sectors? Do service firms differ from manufacturing firms? Another promising avenue for future research would be to examine the effectiveness of compensation programs, as did Cravens et al. (1993), Harrison et al., (1996) and Banker et al. (1996). Are organizations that comply with the theoretical basics more effective than others? As the results of 
Cravens et al. suggest, are certain forms of compensation more effective than others in specific sales activities? In what context should bonuses be offered instead of commissions? Our research also enabled us to test the foundations of the main emerging theories in sales compensation, in a cultural context other than American. Although to a large extent our results have confirmed those obtained by other researchers, it is nevertheless important, in light of the growing trend toward market globalization, to perform comparative studies in order to identify the extent to which the cultural environment and values act on the determinants and effectiveness of sales compensation policies.

\section{Limitations and practical implications}

Despite its contributions, this study had a number of limitations. First, despite the large number of respondents, our sampling of the sales team was not designed to be representative of industries. The sample method restricted our ability to extend the results to other sales organizations. Second, the methods used to gather and analyze the data should be considered. The research design was cross-sectional, and it is thus not possible to infer a causal relationship. The third limitation is that all variables, both independent and dependent, derive from the same questionnaire. This raises concerns about share variance due to a common measurement method. No statistical technique provides proof of causation. A structural equation under LISREL could be used to overcome this problem, as it would factor in measurement errors in variable estimates (Brannick, 1995). Fourth, our units of analysis were sales managers. If we had used human resources managers or salespeople, our results may have been different. This underscores the importance of adopting more than one standpoint. Despite these limits, however, our research has confirmed the relevance of considering several theoretical approaches and using multidisciplinary research to understand why organizations decide on a particular compensation policy for their sales staff.

The key implication for management that comes from this study is that sales compensation is complex and it takes a broad set of sales units and organizational factors to define the proper mix between salary and variable pay. Findings from our hypotheses suggest that managers responsible for sales compensation must be aware that the nature and environment of selling 
activities, resources offered to salespeople, the strategy of human resources management and the qualities of human resources may influence the design of optimal pay policies. More specifically, in organizations where the span of control is high, where the sales force performs non-selling activities, sales closing requires teamwork and considerable time, several expenses related to selling activities are offered and many career opportunities exist, a high salary component seems to be the most indicated strategy. Conversely, in organizations where the products or services are not standardized, that is to say, the sales force can adapt them to meet the needs of customers, selling activities principally take place outside of the establishment and there is a broad disparity in performance and experience between salespeople, high variable pay would be the preferred strategy. Organizations that determine their pay strategy by simply imitating their competitors' pay strategies without considering sales and individual factors identified in this study are likely to attain a less desirable mix between salary and variable pay, and thus may lose a potential competitive opportunity. 


\section{References}

ANDERSON, E. (1985). The Salesperson as Outside Agent or Employee: A Transaction Cost Analysis. Marketing Science, 4, 3, 234-254.

ANDERSON, E. \& RICHARD L. O. (1987). Perspectives on Behavior-Based Versus Outcome-Based Salesforce Control Systems. Journal of Marketing, 51, October, 76-88.

ANDERSON, R. E., HAIR, J. R. Jr. \& BUSH, A. J. (1992). Professionnal Sales Management, Second Edition, McGraw-Hill Series in Marketing, 12.

BALKIN, D. B. \& GOMEZ-MEJIA, L. R. (1987). Toward a Contingency Theory of Compensation Strategy. Strategic Management Journal, 8, 169182.

BALKIN, D. B.\& GOMEZ-MEJIA, L. R. (1990). Matching Compensation and Organizational Strategies. Strategic Management Journal, 11, 153-169.

BALKIN, D. B. \& BANNISTER, B, D. (1993). Explaining Pay Forms for Strategic Employee Groups in Organizations: A Resource Dependence Perspective. Journal of Occupational and Organizational Psychology, 66, 139-151.

BANKER, R.D., LEE, S.Y., POTTER, G. \& SRINIVAN, D. (1996). Contextual Analysis of Performance Impacts of Outcome-Based Incentive Compensation. Academy of Management Journal, 39,4, 920-948.

BARTOL, K.M., \& MARTIN, D.C. (1988). Influence on Managerial Pay Allocations : A Dependency Perspective. Personnel Psychology, 41, 361-378

BARRINGER, M.W. \& MILKOVICH, G.T. (1998) A Theoretical Exploration of the Adoption and Design of Flexible Benefit Plans : A Case of Human Resource Innovation. Academy of Management Review, 23, 2, 305324.

BASU, A. K., LAL, R. SRINIVASAN, V. \& STAELIN, R. (1985). Salesforce Compensation Plans: An Agency Theoretic Perspective. Marketing Science, 
4, Fall, 267-291.

BLESSINGTON, M. (1992). Designing a Sales Strategy with the Customer in Mind.. Compensation and Benefits Review, March-April, 30-41.

BRANNIK, N (1995). Critical Comments on Applying Covariance Structure Modeling. Journal of Organizational Behavior, 27, 1, 56-72.

CESPEDES, F.V. (1990). A Preface to Payment: Designing a Sales Compensation Plan. Sloan Management Review, Fall, 59-69.

COUGHLAN, A. T. \& NARASIMHAN, C. (1992). An Empirical Analysis of Sales-Force Compensation Plans. Journal of Business, 65, 1, 93-121.

COUGHLAN, A. T. \& SEN, S. K. (1989). Salesforce Compensation: Theory and Managerial Implications. Marketing Science, 8, 4, 324-342.

CRAVENS, D.W., INGRAM, T. N., LAFORGE, R. W. \& YOUNG, C. E. (1993). Behavior-Based and Outcome-Based Salesforce Control Systems. Journal of Marketing, 57, October, 47-59.

CRYSTAL, G. (1991). Common Mistakes in Current Practice. In Executive Compensation, (F. R . Foulkes, ed.). Havard Business School Press, 169-188.

DARLINGTON, R., (1968). Multiple Regression in Psychological Research and Practice. Psychological Bulletin, 69, 161-182.

EISENHARDT, K. M. (1985). Control: Organizational and Economic Approaches. Management Science, 31, 134-149.

EISENHARDT, K. M. (1988). Agency and Institutional-Theory Explanations: The Case of Retail Sales Compensation. Academy of Management Journal, $31,3,488-511$.

EISENHARDT, K. M. (1989). Agency Theory: An Assessment and Review. Academy of Management Review, 14, 1, 57-74.

GERHART, B., MILKOVICH, G.T., (1990). Organizational Differences in Managerial Compensation and Financial Performance, Academy of 
Management Journal, 35, 663-691.

GOMEZ-MEJIA, L. R. \& BALKIN, D. B. (1987). Pay Compression in an Acedemic Environment: The Case of Business Schools. . In New Perspectives on Compensation, (D. B. Balkin \& L. R. Gomez-Mejia, Eds), Englewood Cliffs, NJ: Prentice Hall Inc.

GOMEZ-MEJIA, L. R. \& BALKIN, D . B. (1992). Compensation, Organizational Strategy and Firm Performance. Cincinnati, Ohio: SouthWestern Publishing Co.

GREENNING, D.W. \& GRAY, B.G. (1994). Testing a Model of Organizational Response to Social and Political Issues. Academy of Management Journal, 37, 467-498.

HARRISON, D.A., VIRICK, M. \& WILLIAM, S. (1996). Working Without a Net: Time, Performance, and Turnover Under Maximally Contingent Rewards, Journal of Applied Psychology, 81, 4, 331-345.

HURWICH, M. R. \& MOYNAHAN, J. K. (1988). Designing Sales Compensation Plans to Keep Pace with Fast-Moving High-Tech Firms. In The Compensation Sourcebook, (C. H. Fay et R. W. Beatty, Eds). Human Resource Development Press, Amherst, Mass. 384-387.

JOHN, G. \& WEITZ, B. (1989). Salesforce Compensation: An Empirical Investigation of Factors Related to Use of Salary Versus Incentive Compensation. Journal of Marketing Research, 26, February, 1-14.

JOHNSON, S. T. (1993). Sales Compensation: In Search of a Better Solution. Compensation and Benefits Review, November-December, 53-60.

KOWTHA, N.R. (1997). Skills, Incentives, and Control : An integration of agency and transaction cost approaches. Group \& Organization Management, 22, 1, 53-86.

LAL, R. (1986). Delegating Pricing Responsibility to the Salesforce. Marketing Science, 5, 2, 159-168.

LAL, R. \& SRINIVASAN, V. (1993). Compensation Plans for Single and 
Multi-product Salesforces: An Application of the Holmstrom-Milgrom Model. Management Science, 39, 7, 777-793.

MILKOVICH, G. T. (1988). A Strategic Perspective on Compensation Management. In Research in Personnel and Human Resources Management, (K. Rowland \& G. Ferris, eds) CT: JAI Press, 6.

MOYNAHAN, J. K. \& LOCKE, G . M. (1988). Designing an Effective Sales Compensation Program. In The Compensation Sourcebook, (C.H. Fay \& R.W. Beatty, eds.). Amherst, Mass: Human Resource Development Press, 380-383.

OUCHI, W. Z. (1979). A Conceptual Framework for the Design of Organizational Control Mechanisms. Management Science, 25, September, 833-847.

PFEFFER, J. \& SALANCIK, G. . (1978). The External Control of Organizations: A Resource Dependence Perspective. New York, Harper \& Row.

PFEFFER, J. \& DAVIS-BLAKE, A. (1987). Understanding Organizational Wage Structures: A Resource Dependence Approach. Academy of Management Journal, 30, 437-455.

ROTH, K. \& O'DONNELL, S. (1996). Foreign Subsidiary Compensation Strategy: An Agency Theory Perspective. Academy of Management Journal, 39, 3, 678-703.

SCHULTZ, C. F. (1987). Compensating the Sales Professional. In New Perspectives on Compensation, (D. B. Balkin \& L. R. Gomez-Mejia, eds). Englewood Cliffs, NJ: Prentice-Hall, 250-257.

STROH, L.K., BRETT, J.M., BAUMANN, J.P. \& REILLY, A.H. (1996). Agency Theory and Variable Pay Compensation Strategies. Academy of Management Journal, 39, 3, 751-767.

TREMBLAY, M. \& MARCOUX, D. (1994). The Determinants of BlueCollar Employees' Compensation in Quebec Municipalities (in French). 
Relations Industrielles, 49, 3, 528-547.

WILlIAMSON, O. E. (1975). Markets and Hierarchies: Analysis and Anti-Trust Implications, New York: The Free Press.

WILLIAMSON, O. E. (1979). Transaction-Cost Economics: The Governance of Contractuel Relations. Journal of Law and Economics, 22, October, 233261.

WILLIAMSON, O. E. (1985). The Economic Institutions of Capitalism, New York: Free Press. 
Appendix 1: Summary of Variables and Abbreviations

\begin{tabular}{|c|c|c|}
\hline Variables & Description & Key constructs \\
\hline Proportion of salary & Salary component in total compensation ( \%) & Dependent variable \\
\hline Programmability & Customer's effort in purchase. (1) low, (3) high & Programmability \\
\hline Ratio & Number of supervisors to number of salespeople & Observation \\
\hline Workplace & On the road (1) or in the office $(0)$ & Observation \\
\hline Days on the road & Number of days on the road (1-5) & Observation \\
\hline Measure of outputs & $\begin{array}{l}\text { Three items assessing the ease with which the results } \\
\text { can be measured (1) disagree (7) agree }\end{array}$ & Measure of outcomes \\
\hline Support activities & Sales support activities $(\mathrm{yes}=0, \mathrm{no}=1)$ & Measure of outcomes \\
\hline Support importance & $\begin{array}{l}\text { Percentage granted to sales support }(0 \%-100 \%) \text { in five } \\
\text { categories }\end{array}$ & Measure of outcomes \\
\hline Team sales & $\begin{array}{l}\text { Five items assessing the need for cooperation } \\
\text { In closing sales (1) disagree ( } 7 \text { ) agree }\end{array}$ & Measure of outcomes \\
\hline Growth potential & Product with growth potential (yes $=1, \mathrm{no}=0$ ) & Sales uncertainty \\
\hline Market share & Relative market share $(1=$ high, $0=$ low $)$ & Sales uncertainty \\
\hline Time to close a sale & Time needed to close a sale (hours) & Sales uncertainty \\
\hline Number of meetings & Number of meetings to close a sale & Sales uncertainty \\
\hline Product adaptability & Product adaptability (yes $=1$, no $=0$ ) & Product resources \\
\hline $\begin{array}{l}\text { Product } \\
\text { complementary }\end{array}$ & Product complementarity $(\mathrm{yes}=1, \mathrm{no}=0$ ) & Product resources \\
\hline \begin{tabular}{|l|l} 
Resources \\
availability
\end{tabular} & $\begin{array}{l}\text { Number of resources available to salespeople } \\
\text { (possibility of six) }\end{array}$ & Product resources \\
\hline $\begin{array}{l}\text { Discretionary } \\
\text { expenses }\end{array}$ & $\begin{array}{l}\text { Existence of a discretionary expenses account (yes }=1 \text {, } \\
\text { no=0) }\end{array}$ & Financial resources \\
\hline Size of expenses & Size of expense account per month ( $\$$ in 5 categories) & Financial resources \\
\hline Number of expenses & Number of expenses covered by the organization & Financial resources \\
\hline Training effort & Training effort required (1) minimal, (7) major & Specific assests \\
\hline Training budget & Training budget ( $\$$ in six categories) & Specific assests \\
\hline Career plan & Presence of formal career plan (yes $=1$ ) & Specific assests \\
\hline Number of levels & Number of reporting levels in the sales function & Specific assests \\
\hline Sale predominance & $\begin{array}{l}\text { Percentage accorded to sales team in the marketing mix } \\
(0 \% \text { to } 100 \% \text { in six categories })\end{array}$ & Marginal productivity \\
\hline $\begin{array}{l}\text { Performance } \\
\text { differential }\end{array}$ & $\begin{array}{l}\text { Differential between salespeople performance } \\
\text { (1) no difference, (7) more } 100 \%\end{array}$ & Marginal productivity \\
\hline Education & Level of education (1) secondary, (4) Master's & Competency \\
\hline Experience & Experience in sales (years, in four categories) & Competency \\
\hline Turnover & Staff turnover (\% in six categories) & Competency \\
\hline Size of firm & Turnover (\$ in six digit) & Control variable \\
\hline Retail & Retail sector $(1)$ others $(0)$ & Control variable \\
\hline Manufacturing & Manufacturing sector $(1)$ others $(0)$ & Control variable \\
\hline Financial & Finance, insurance and real estate sector $(1)$ others $(0)$ & Control variable \\
\hline Services & Services sector $(1)$ others $(0)$ & Control variable \\
\hline Communication & Communication / transport/public utilities (1) others (0) & Control variable \\
\hline
\end{tabular}




\section{Liste des publications au CIRANO *}

\section{Cahiers CIRANO / CIRANO Papers (ISSN 1198-8169)}

96c-1 Peut-on créer des emplois en réglementant le temps de travail ? / Robert Lacroix

95c-2 Anomalies de marché et sélection des titres au Canada / Richard Guay, Jean-François L'Her et Jean-Marc Suret

95c-1 La réglementation incitative / Marcel Boyer

94c-3 L'importance relative des gouvernements : causes, conséquences et organisations alternative / Claude Montmarquette

94c-2 Commercial Bankruptcy and Financial Reorganization in Canada / Jocelyn Martel

94c-1 Faire ou faire faire : La perspective de l'économie des organisations / Michel Patry

\section{Série Scientifique / Scientific Series (ISSN 1198-8177)}

98s-27 The Moderating Effect of Job Characteristics on Managers' Reactions to Career Plateau / Michel Tremblay et Alain Roger

98s-26 Une étude internationale sur la contingence de l'efficacité perçue des politiques de rémunération / Michel Tremblay, Bruno Sire et Denis Chênevert

98s-25 Resources Dynamics and Endogenous Property Rights Regimes / Ngo Van Long et Huilan Tian

98s-24 Plafonnement objectif et subjectif de carrière, satisfaction et stress au travail / Alain Roger et Michel Tremblay

98s-23 The Role of Organizational Justice in Pay and Employee Benefit Satisfaction, and Its Effects on Work Attitudes / Michel Tremblay, Bruno Sire et David Balkin

98s-22 What Data Should Be Used to Price Options? / Mikhail Chernov et Eric Ghysels

98s-21 Using a Financial Training Criterion Rather than a Prediction Criterion / Yoshua Bengio

98s-20 Inférence fondée sur les statistiques des rendements à long terme / Cosme Vodounou

98s-19 Structural Change Tests for Simulated Method of Moments / Eric Ghysels et Alain Guay

98s-18 Managing the Risk of IT Outsourcing / Benoit A. Aubert, Sylvie Dussault, Michel Patry et Suzanne Rivard

98s-17 Learning Conditions in the Context of R\&D and Development Projects: Empirical Evidence from a Research Centre / Mario Bourgault et Hélène Sicotte

98s-16 Assessing the Risk of IT Outsourcing / Benoit A. Aubert, Michel Patry et Suzanne Rivard

98s-15 Determinants of Desired Career Paths among Canadian Engineers / Michel Tremblay, Thierry Wils et Caroline Proulx

98s-14 Why Is the Bid Price Greater than the Ask? Price Discovery during the Nasdaq Pre-Opening / Charles Cao, Eric Ghysels et Frank Hatheway

98s-13 "Informal Thinkering": How Is It Important? / Pierre J. Tremblay

98s-12 Organize to Generate Innovation: Tools to Measure Technical Change, Productivity and Change-Generating Efforts / Pierre J. Tremblay

* Vous pouvez consulter la liste complète des publications du CIRANO et les publications elles-mêmes sur notre site World Wide Web à l'adresse suivante :

http://www.cirano.umontreal.ca/publication/page1.html 